\title{
Oakeshott's Theory of Freedom as Recognized Contingency
}

European Fournal of Political Theory

\author{
Efraim Podoksik Bilkent University, Turkey
}

Aв STRACT: This article argues that Oakeshott's theory of freedom possesses a greater degree of coherence than is often perceived. Freedom in Oakeshott's philosophy may be defined as 'recognized contingency', combining the notions of a genuine choice of action and of an agent's awareness of having such a choice. Oakeshott employs his notion of freedom in two different contexts. One is the context in which freedom is understood as a concept distinguishing what is conceived as 'human' from what is conceived as 'non-human'. The other context is that of membership in societies, which under certain circumstances can be characterized either by the presence or the lack of freedom. The article argues that, while at first glance Oakeshott's ideas look counter-intuitive, at a deeper level this understanding of freedom is akin to that prevalent in the consciousness of modern liberal societies.

K E Y W O R D : choice, civil association, contingency, freedom, buman agency, idealism, liberalism, negative liberty, Oakeshott, rule of law

\section{Introduction}

It is widely recognized that the idea of freedom lies at the heart of Michael Oakeshott's social thought. According to Noel O'Sullivan, the main feature of Oakeshott's temperament was 'a love of freedom so radical and uncompromising that it imbued his conservatism with existentialist, and even anarchist, sympathies'. ${ }^{1}$ In On Human Conduct freedom occupies the central place. It is described by Oakeshott as a postulate of human conduct in general, and as an underlying principle of the civil association. Yet the idea of freedom in Oakeshott's philosophy has not received due attention from commentators, at least in comparison with other much discussed themes such as rationalism, ideology and tradition. This can be partly explained by the fact that, although the value of freedom is strongly accentuated in Oakeshott's late writings, the actual description of what

Contact address: Dr Efraim Podoksik, Bilkent University, Department of Political

Science, o6533 Bilkent, Ankara, Turkey.

Email: E.Podoksik@cantab.net 
he means by freedom is brief and dense, and perhaps incomplete. Various interpreters find it difficult to present a detailed and coherent analysis of a concept described in a few paragraphs.

The most scrupulous analysis of Oakeshott's theory of freedom in his late writings has been undertaken by John Liddington, according to whom Oakeshott uses the word 'freedom' in three different meanings: freedom of human agency, political freedom and substantive freedom. ${ }^{2}$ Liddington finds all three meanings partly confused, contradictory and unconvincing. Although Liddington's interpretation has been challenged at some points, his article still remains the most important and comprehensive treatment of the subject, since it provides us with the fullest account of Oakeshott's position. ${ }^{3}$

In this article I have undertaken to present Oakeshott's theory of freedom in a different light. Taking Liddington's argument as the starting point, I try to show that his interpretation of Oakeshott's position is misleading. I argue that Oakeshott held a coherent, simple and rather elegant view of freedom. Unfortunately, Oakeshott is partly to blame himself for the misinterpretations, for he never articulated the idea of freedom in a clear way and did not publish any response to criticisms of his position. Therefore, my account is merely the interpretation of what I take Oakeshott's underlying view to be, but this is not an arbitrary interpretation. I intend to show that, if Oakeshott's ideas are to be taken seriously, this is the most plausible interpretation which is implied in the text itself.

The view that I want to present is as follows. For Oakeshott, the term 'freedom' always refers to the same concept consisting of two mutually dependent characteristics - 'reflectivity' and 'contingency'. However, Oakeshott uses the concept of freedom in two different contexts. One is the context in which freedom is employed as a concept distinguishing what is understood as 'human' from what is understood as 'non-human'. The other is that of human beings, understood as members of societies, which under certain circumstances can be characterized either by the presence or the lack of freedom. The application of the idea of 'recognized contingency' makes a specific meaning of 'freedom' different in those two contexts. I will refer to 'recognized contingency' in the first context as 'human freedom', and in the second context as 'civil freedom'.

This interpretation of Oakeshott's idea of freedom will lead us to two important conclusions. First, although Oakeshott repudiates the extreme utilitarian concept of freedom, according to which freedom is correlative of the amount of physical and legal restrictions on human actions, his views correspond to the basic intuitions of the modern western liberal consciousness and lie within the philosophical tradition akin to what is known as 'negative liberty'. Second, Oakeshott's position is extremely helpful in providing answers to some difficulties often discussed in recent debates on the meaning of freedom. 


\section{Human Freedom}

According to Oakeshott's view outlined in On Human Conduct, freedom is intrinsic to human conduct as such, for it is postulated in our understanding of human agency. A postulate in Oakeshott's terminology means an unquestioned presupposition on which any judgment or investigation of a particular identity is based. Thus, reality is a series of experienced events, or 'goings-on'. In order to become intelligible such 'goings-on' must be identified by being understood in terms of ideal characters specified as a composition of characteristics. Every such understanding is based upon an uncriticized assumption. Such assumptions cannot be questioned in the process of identifying 'goings-on', for they constitute a 'platform' of investigation.

To investigate this platform, that is the postulates on which a certain ideal character is based, is a different undertaking. A confusion between the investigation of postulates and the investigation of a particular situation analysed under these postulates should be avoided. A postulate does not presuppose any particular outcome:

To read the face of Big Ben (that is, to 'tell the time') postulates and therefore does not interrogate the idea 'time'; 'time' here is unproblematic; the problem is, 'What is the time?' And to understand a 'going-on' such as 'my friend Tom considering which of two hats he shall buy' postulates and therefore does not interrogate the ideas 'deliberation' and 'choice'. ${ }^{4}$

Therefore, when Oakeshott says that human conduct postulates a 'free agent', he means that human actions cannot be understood without the presupposition that freedom is somehow intrinsic to them. Freedom is not something that may be present or absent, may be more or less. Human conduct can be understood only as a free conduct, and therefore freedom, thus understood, cannot determine any particular performance of action. In other words, every act of every human agent is a free act. How is this possible and what conclusions can be derived from this assumption?

Oakeshott distinguishes between two categories of identities, each of them inviting a different order of inquiry. The first category includes 'goings-on' which are not themselves exhibitions of intelligence, like rock formations or a chameleon changing colour. To understand them means to grasp conditions which somehow determine what is occurring, but the operation of which does not require our understanding or learning them. These conditions are not an acting intelligence and are therefore devoid of any meaning apart from the fact of their having happened. Here the relationship between the conditioned and conditional is understood as a causally determined process.

The other category includes 'goings-on' which are themselves exhibitions of intelligence, like the engagement of understanding. They are understood in terms of what Oakeshott calls practice, which can be described as 'the ordered context from which the performance draws its meaning'. ${ }^{6}$ In other words, prac- 
tice does not determine a specific content of any act, but creates a cultural context which gives the meaning to a particular action. Thus, the procedure of election does not cause a participant to vote for a specific candidate, but enables us to understand the meaning of his act of voting (or not voting). Evoking the hermeneutic approach, Oakeshott insists that it is impossible to give an account of an intelligent action without learning its meaning for the agent himself.

These two categories are exclusive of one another. The 'goings-on' understood as a process cannot be understood as a practice and vice versa, since practice only creates the meaningful context of action, while process determines its content. This does not mean that a certain 'going-on' has got a predisposed character which defines it as either intelligible or non-intelligible. Indeed any event can be treated in both ways. Thus, human behaviour can be understood either as an effect of biochemical process, or a meaningfully chosen act. What should be avoided is the confusion of what order of inquiry is undertaken.

Oakeshott understands human conduct as a category of inquiry which is itself an exhibition of intelligence. Any attempt to combine this inquiry with the view of human conduct as a result of 'process' is therefore excluded by definition. Human conduct is understood as an intelligent identity, and freedom is a postulate of such conduct. Therefore, freedom is inherent in our understanding of human nature. But what does Oakeshott mean by this word?

I suggest that freedom can be identified as 'recognized contingency'. It contains two interdependent aspects - reflectivity and contingency. In order to show how it can be plausibly argued that freedom is presupposed in human conduct, I will analyse these two aspects separately, but it is important to realize that they, in fact, represent an unseparate whole.

\section{Reflectivity}

Human conduct is the exhibition of intelligence. The human world is a world of understanding and meaning. The intelligibility of a situation is what makes an agent 'free'. The human agent is 'reflective consciousness', and freedom is presupposed by his self-understanding and not by free will. As Oakeshott points out, an agent "is "free" not because his situation is alterable by an act of unconstrained "will" but because it is an understood situation and because doing is an intelligent engagement'.

This world of meanings must be learned, and learning is inseparable from being human. ${ }^{8}$ Understanding can be achieved only in an individual way, for

... if two or more agents have similar understandings of their situation this is because they have independently learned to think alike and not because they share common organic tensions, have similar genetic characters, or have suffered or enjoyed like external circumstances. ${ }^{9}$ 
The idea of freedom presented in such a way is reminiscent of either the Stoic concept of freedom, or of the Hegelian view of will as derivative from thought. ${ }^{10}$ It seems to stand far away from the empiricist view of freedom characteristic of English philosophy. This leads such commentators as Robert Devigne to place Oakeshott among those who spurn the idea of negative liberty. ${ }^{11}$

Indeed, in various places Oakeshott evokes a quasi-Hegelian vocabulary, saying, for example, that 'a human being is "free", not because he has "free will", but because he is in himself what he is for himself. ${ }^{12}$ But whatever this Hegelian phraseology may mean, Oakeshott's view must be sharply distinguished from the Hegelian view in particular and the post-Kantian German philosophies of freedom in general.

First, Oakeshott explicitly states that he is not preoccupied with various metaphysical or teleological meanings of freedom, pointing out that he is concerned "not with the quality of being substantively "self-directed" which an agent may or may not achieve and which, when a high degree of it is enjoyed, is properly called "self-determination" or "autonomy". ${ }^{13}$

Second, although freedom always involves 'thought' it does not involve merely thought, for thought relates to doing, and doing is always understood through the contingency of a specific situation.

\section{Contingency}

Far from advocating 'rationality' of thought Oakeshott puts emphasis on intelligence in order to highlight the significance of choice and deliberation in a human action. Freedom for him does not mean awareness per se, but the awareness of a situation. This situation, so long as it is seen as one's own situation, always demands a response from the agent. This response cannot be determined and it always necessitates the choice to do this rather than that. The quality of choice is unimportant here, for the decision to do something may be stupid as well as clever. The important feature of it is the necessity of choice itself.

Oakeshott calls this situation 'contingent'. For him a contingent relationship is

... a sequential relationship of intelligent individual occurrences where what comes after is recognized to be conditional upon what went before . . . because they 'touch' and in touching identify themselves as belonging together and as composing an intelligible continuity of conditionally dependent occurrences. ${ }^{14}$

In other words, contingency for Oakeshott is not a relationship by accident. ${ }^{15}$ It is rather such connection between two events in which the consequent event acquires meaning in the context of the antecedent event, but is not determined by it. Contingency presupposes indeterminacy. ${ }^{16}$

Now, one can see that although we have distinguished between reflectivity and contingency, they presuppose and depend on each other, for 'in an agent's understanding of his situation its contingency is postulated'. ${ }^{17}$ This means that a con- 
scious agent must find his situation as one in which he is supposed to make an indeterminate performance. Likewise, if one is speaking about a situation the outcome of which is not determinate, he presupposes the involvement of an intelligent actor.

Thus, Oakeshott's view of human freedom seems to refer to the philosophical tradition which emphasizes inner 'thought' rather than external constraint in its definition of freedom. Yet it incorporates basic modern intuitions about freedom as a freedom of choice. Indeed, Oakeshott's approach makes the distinction between free will, free choice and free action obsolete. There is no separate faculty such as free will, existing even if there is no freedom of action. Every human action is a free action, and it is free because it is never the only possible action. There is always an awareness of the presence of choice to do this or that. Every action is always seen as a result of free choice. But does such combination of reflectivity and action look plausible?

One can argue that there are some situations in which freedom of choice is absent or is severely limited. In this case, one should either claim that an agent is unfree, or redefine freedom in a purely inner way to avoid dealing with conduct. But this is not Oakeshott's position since he maintains that all human agents are free, and also that choice is an important aspect of freedom.

The response may be as follows. In so far as one understands himself as a human agent, he will not see his situation as devoid of any choice. Even the conduct of a prisoner is indeterminate so that he may choose to perform what he is allowed or is required to do in different ways. A slave can decide either to obey or to disobey and be killed, but this is bis own decision.

Oakeshott, however, does not mean that slaves and prisoners are socially free, and this is why it is necessary to distinguish between two contexts of the use of the term 'freedom'. In the context of social relations, freedom is understood differently. But in so far as one wants to understand what it means to be a human agent, in comparison with a broom, it is quite plausible to come to the conclusion that the two are distinguished by the fact that a human being is free, while a broom is not. Thus, when a slave compares himself with free citizens, he thinks about himself as socially unfree. But if he asks himself whether there is any difference between him and the broom of his master, since both are subject to the master and do the same work, his answer perhaps will be that the broom is unfree to choose to disobey. In this context it will be perfectly legitimate to use the term 'freedom' in such a sense. Moreover, even one's thoughts can be understood as acts, so that one who is tied by chains finds himself in the situation of indeterminacy, as long as he can make a choice of what to think. 


\section{Civil Freedom}

In the context of a social relationship, however, Oakeshott does not discuss in what sense a human being as such can be seen as free compared with non-human beings, but rather, in what sense a member of a society can be free or not with regard to a different kind of society. ${ }^{18}$

Oakeshott distinguishes between two kinds of durable social relationships in which human agents can be engaged - enterprise association and civil association. The enterprise association is one in which members are united in order to achieve some common substantive purpose. This purpose may be clear or vague, simple or complex. However, the existence of such purpose is the main characteristic of this kind of association. This is a relationship in terms of 'management', since the members must have an acknowledged way of making circumstantial decisions to do this rather than that in order to respond to a situation and to achieve a result. The association may have rules, but the reason for the existence of these rules is prudential. It is whether and how well they promote the pursuit of the common purpose. ${ }^{19}$

The other kind is called by Oakeshott 'civil association'. The members of the civil association, by contrast, are related not in terms of common purpose but in terms of moral practice. What characterizes such an association is a subscription to common, general and articulated rules, which are called lex. The word lex does not signify every law but only the law which is formulated in terms of subscription to general practice and which does not require substantive performances. Lex does not prescribe what one must do but rather sets conditional rules to which substantive performances must be subscribed. ${ }^{20}$

The membership in both kinds of associations may be voluntary or compulsory. If it is voluntary, so that a member may leave his association at any time, such a member is certainly free, and no theoretical problem arises. Therefore, freedom in a voluntary enterprise association exists, for its members can voluntarily choose to cancel their membership. ${ }^{21}$

A really important question is whether freedom may exist in an association in which the membership is compulsory. Oakeshott gives different answers with respect to the two modes of association. He insists that the members of the compulsory enterprise association are unfree, while the members of the compulsory civil association are free. The importance of this question lies in the fact that the modern state is, undoubtedly, a compulsory association. Even if one is allowed to leave his state he is likely to find himself in another state. Therefore, according to Oakeshott, citizens of any state could be considered free only to the extent that their state is seen as a civil association.

Why do citizens remain free in a compulsory civil association? The answer lies in the character of its law. Lex, as a system of general rules, does not command substantive performances but merely imposes certain conditions on our choices: 
The appearance procedures and rules may have of excluding (forbidding), or more rarely of enjoining, substantive choices and actions is illusive. Practices identify actions adverbially; they exclude (forbid) or enjoin them in terms of prescribed conditions. A criminal law, which may be thought to come nearest to forbidding actions, does not forbid killing or lighting a fire, it forbids killing 'murderously' or lighting a fire 'arsonically'; and these adverbs are narrowly specified in terms of the evidence required to substantiate or to rebut the considerations alleged..$^{22}$

Rules do not prescribe a substantive performance, and subscription to them does not remove from an agent the possibility of recognizing himself in a contingent situation in which he is able to make a choice to do this rather than that, and thus remain free. No realm can escape the authority of law. As John Coats interprets it, 'for Oakeshott, the freedom of citizens arises not in the silence but in the generality of the laws'. ${ }^{23}$ Freedom is dependent on the adverbial character of law in the civil condition. Thus, Oakeshott opens the way to the reconciliation between law and freedom.

The idea of the indeterminacy of human conduct in the civil association (the freedom to chose this rather than that) is stressed by Oakeshott several times, which lets Liddington claim that this view of freedom (which he calls 'substantive' freedom) lies at the heart of Oakeshott's view. ${ }^{24}$ But it is easy to see that the principle of adverbiality does not provide us with any criterion of distinction between the civil and enterprise association. For, according to Oakeshott, no system of rules can determine substantive performances, because any maxim formulated on any level of generality will leave room for variations when applied to practice. ${ }^{25}$ Oakeshott himself admits that general rules exist in the enterprise association as well. If this is the case, then the members of the enterprise association are not less free than the members of the civil association. One can imagine such an association in which the purpose is pursued only by means of general rules and not specific commands.

Further, the idea of the adverbial character of lex seems to be counter-intuitive and contradictory in itself, so that it invites almost indefensible attacks, particularly from the utilitarian liberal view. Thus, Liddington, while agreeing that there are many laws which seem to be formal, such as contract laws, puts the question of whether every law can be formal:

If a law prohibiting murder can be a procedural law, what would not count as a procedural law? If a law prohibiting fire-raising may be said to qualify rather than determine the performance of fire-lighting, why may not a law prohibiting (say) 'bourgeois' education be said to qualify rather than determine the performance of learning and teaching. And if, as Oakeshott's view would seem to imply, a law prohibiting larceny does not necessarily restrict substantive freedom, why should we suppose that a law prohibiting private property necessarily restricts it? ${ }^{26}$

This is indeed a very strong criticism. Moreover, the problem remains even when one considers laws which are enacted in order to promote basic freedoms, such 
as a law which regulates the freedom of demonstration. For, although the essence of this law may be providing the most favourable conditions for all groups to demonstrate peacefully, still it must restrict some substantive actions in order to create the conditions of peace and security. It is difficult to see at first glance how these laws do not restrict freedom at all.

What can be said as a possible defence against this criticism? The first claim may be prudential, like that of Hayek, that the rule by general laws is not likely to lead to the violation of freedom, since those who enact such laws will also have to comply with them. ${ }^{27}$ Whatever the plausibility of such a claim may be, it does not refute the criticisms against Oakeshott, since Oakeshott himself rejects any prudential considerations in his discussion.

Second, one can argue that not only should laws be formulated in an adverbial way, but they must be non-substantive in their content. According to Coats, 'if a putative practice of authority included stipulations sufficiently specific as to be unambiguously performable in single actions, it would expose itself . . as an "instrumental" practice only masquerading as a "civil" practice'. ${ }^{28}$

But in order to know which laws are really 'civil' and which ones only pretend to be 'civil', one needs an external criterion of what is counted as 'unambiguously specific'. Thus, the criterion of adverbiality cannot stand on its own feet and serve as an ultimate guide for what is regarded as lex. But it is even dubious whether an objective criterion for what is 'unambiguously specific' can be found at all. Consider the example of the demonstration law. Such law may have two different purposes. In a free democratic state its main purpose is to ensure the peaceful and orderly character of any demonstration and also to provide a guarantee for as many groups as possible to use this right. Thus, the law may require the registration with police, whose function is not to limit the expression of different ideas but to prevent the outbreak of violent disturbances. On the other hand, in a dictatorship the demonstration law may be used in order to forbid the expression of some views and ideas. As both laws may sound identical, one should look not only at their texts but also at their actual implementation in order to know what their character is.

Third, one can say that Oakeshott's claim that formal laws are fully compatible with freedom is simply a rhetorical exaggeration, and that he perhaps wants to say that freedom is almost not constrained by such laws, or that it is not constrained significantly. But this interpretation would just mean that one refuses to take Oakeshott's argument seriously. For, whatever obscurities can be found in Oakeshott's text, it is absolutely plain that he thinks that formal laws do not limit freedom at all.

Thus, all these attempts to compromise the meaning of Oakeshott's argument are inadequate. The concept of 'substantive' freedom seems neither to be correct in itself, nor to provide and maintain a valid distinction between the two kinds of association.

Yet another meaning of freedom is sometimes derived from Oakeshott's 
writings. This is what Liddington calls 'political' freedom, and what is regarded as the essential element of Oakeshott's view by many other interpreters. ${ }^{29}$ Sometimes Oakeshott argues that freedom in the civil association is derivative from the non-purposive character of such an association. As no purpose exists, no need arises to demand citizens' approval of the purpose of their alleged enterprise. The authority of lex is sovereign and self-sufficient. The authority of rules is separated from their approval. The rules do not need to be approved in order to be subscribed, and disapproval cannot be a reason for disobedience. Lex cannot include the requirement of belief. As Oakeshott says, 'the reason for this veto is the impossibility of such a requirement being authoritative, not the impossibility of its enforcement'. ${ }^{30}$ To claim the opposite would mean that there is some link between acknowledgement and approval, and this would be a selfcontradiction, since the very authority of lex is implied in the fact that it cannot be subject to any considerations of desirability and approval. The member of a compulsory enterprise association cannot be free, since he is obliged to recognize the purpose of his association, whereas the members of the civil association 'are related solely in virtue of their acknowledgment of the authority, not the desirability, of ... prescribed conditions ... There is, then, nothing in civil association to threaten the link between belief and conduct which constitutes "free" agency .... ${ }^{31}$

This idea is treated more favourably by many commentators, perhaps because of its overtones of the classical views of participatory democracy and the possibility of dissent which it provides. It also seems to provide a better answer as to why freedom exists only in the compulsory civil association, for its purposeless character avoids any need of approval of a purpose. Liddington argues that Oakeshott overlooks the possibility of the existence of several purposes at the same association, but I do not think that this criticism holds. These several purposes are either compatible or not. If they are compatible, then the general uniting purpose can be derived from them. If they are not, then some other principle is needed in order to reconcile the conflict between them, such as an idea of the association as a system of not-purposive rules enabling the coexistence of conflicting purposes.

Yet this interpretation of the meaning of freedom is not any more satisfactory than the concept of 'substantive' freedom, mainly because it contradicts the most important of Oakeshott's ideas. First, in the distinction between civil and enterprise association, the emphasis is certainly put on the indeterminacy of choice in subscribing to rules and not on the idea of dissent. Commentators deal with the idea of adverbiality not because they fail to acknowledge that it does not provide a good criterion (as Anthony Farr perhaps implies ${ }^{32}$ ), but simply because of what is said in the text. Oakeshott's idea that the members of an enterprise association are required to perform substantive acts and are denied the choice to do this rather than that, is much more salient than the idea that they cannot express their disapproval of the common purpose. 
Second, the adoption of this interpretation implies conclusions that Oakeshott would certainly reject. Thus, according to this view, prisoners in slave-labour camps are unfree only if these camps are seen as an instrument in some project, such as industrial development. But if these camps exist only as a feature of the association without any purpose, the prisoners would be free, particularly if they are allowed to express their disapproval of their condition. And then, indeed, Steven Gerencser is right, insisting that, if freedom is understood as the right to disapprove the purpose of an association, it should be also seen as the right to disapprove the terms of an association..$^{33}$ But Oakeshott would hardly support this interpretation. Moreover, in one of his earlier essays he explicitly says that some other freedoms are more important than the freedom of speech. ${ }^{34}$

\section{Civil Freedom: Restatement}

Thus, two distinct meanings which Liddington attributes to Oakeshott's theory of freedom have been found implausible and open to serious objections. Can any satisfactory answer be given to these objections? I think that such an answer exists and that it is implied in the text of On Human Conduct without being explicitly stated. In my view, most objections presented here originate in Liddington's misinterpretation of Oakeshott's view of civil freedom, due, partly, to a too scrupulous analysis of the text. This misinterpretation is based on the distinction between formal/substantive and moral/instrumental qualities of law. This distinction is not clearly stated in On Human Conduct, and it is made by Liddington who sees it as necessarily implied in the text.

Substantive law is the law which specifies a substantive performance. Formal law is the law which establishes a set of general rules that qualify but do not determine agent's actions. Laws can be also distinguished by whether they are purposive or not. Thus, there may be laws enacted in order to promote some purpose extraneous to them, and then they are called instrumental. The laws which have no such purpose are called 'moral'. These two distinctions are not connected. Instrumental laws (that is, laws established to achieve some purpose) are not necessarily substantive, since they can prescribe only general rules which promote the achievement of such a purpose. And in my view, moral laws, perhaps, can be substantive if the commands which they contain do not serve any purpose.

As I see it, when Liddington makes this distinction, he naturally comes to distinguish between two kinds of civil freedom. 'Substantive' freedom is concerned with the formal/substantive dimension of law - freedom exists if the law is formal, and does not exist if the law is substantive. 'Political' freedom seems to correspond to the moral/instrumental dimension - freedom dependent on the existence or the absence of the acknowledged common purpose. This analytical distinction can be derived from Oakeshott's argument; moreover his argument seems to require it. Nevertheless, Oakeshott does not clearly formulate this distinction, and ties the existence of a common purpose to the requirement to 
perform a substantive action. Thus, according to him, a member of an enterprise association 'is bound to common substantive action in pursuit of an agreed common purpose..$^{35}$

I claim that this opaqueness is not accidental. On many occasions the difference between formal/substantive and moral/instrumental dimensions is blurred up to the point that Oakeshott contrasts the 'substantive' feature of laws in the enterprise association with the 'moral' quality of laws in the civil association, and seems to imply that the common purpose in an enterprise association somehow makes citizens perform substantive actions. But we have already seen that the question of the 'substantive' character of rules is, strictly speaking, irrelevant to the character of an association. Again, it is possible to imagine such an association which is managed only by general rules, though these rules are designed, and are understood to have been designed, to achieve a certain purpose. Does this mean, then, that Oakeshott's argument suffers from inadvertence?

I think that the answer to this is very simple, if one gets rid of all these distinctions. I claim that no two different meanings of civil freedom ('political' and 'substantive') exist. Indeed, Liddington himself finds that in most of the cases Oakeshott mentions these two freedoms together, while calling them 'civil freedom' ${ }^{36}$ But he fails to draw the obvious conclusion from this fact, which is that Oakeshott does not have in mind two different meanings of freedom. He simply has a twofold understanding of the same civil freedom, when 'political' and 'substantive' are none other than the description of the same concept from different points of view. Indeed in the summarized definition of civil freedom two elements are linked together. Civil freedom is described as 'the condition of being associated solely in terms of the recognition of the authority ... of the adverbial conditions of conduct'. ${ }^{37}$ That is, what is recognized is not authority per se, but the authority of conditions which are always adverbial. In other words, in the civil association only such laws are recognized as authoritative that leave room for a choice in performing an action.

Theoretically, formal/instrumental laws (that is, laws which do not specify performances, but nevertheless promote a certain goal) are possible. But Oakeshott is not concerned with them because he thinks that he can describe the dichotomy between two kinds of association in such a way that substantive demands will presuppose a common purpose, while formal laws will mean the absence of such a purpose.

The claim implied here is that no law possesses objective quality and that the character of any law is determined by citizens' perceptions. Whenever a certain law is grasped as 'substantive' it will be understood as implying some purpose, while when it is perceived as 'formal', it will be seen as lacking such a purpose. Likewise, if an association is grasped as having some purpose, its laws will be perceived as containing substantive demands, whereas, when an association is understood as civil, its laws will not be seen as limiting one's freedom of choice.

It is important that Oakeshott's idealism is taken seriously. The crucial point 
is that, for Oakeshott, social reality is a reality of meanings which exists only in the ideas and experience of human beings, so that no objective 'social reality' can exist. As Jeremy Rayner puts it, 'since the human relationships are an expression of the self-understanding of the agents so related, to grasp the character of an association must necessarily entail understanding the beliefs of the associates' ${ }^{38}$

If one realizes that for Oakeshott 'freedom' is not a material quality but an abstract concept which cannot exist apart from the perceptions of human agents, we can in principle agree that it may quite well be the case that the perception of 'formality' of laws is connected to their purposeless character.

In order to see why this view can be plausible, or at least coherent, let us take an example. The case of traffic laws is frequently presented in debates on freedom, because they are a good example for those authors who appeal to readers' intuitions against what they see as a liberal view of 'negative' liberty. Thus, Charles Taylor claims that we do not perceive these laws as violating our freedom, and believes that this proves that we attribute more significance to some desires and goals than to others. From this point he makes a further step arguing that some desires can be seen as more 'rational' or more 'authentic' than others, and in this sense it is reasonable to speak about 'positive' liberty. ${ }^{39}$

Now, if my analysis of Oakeshott's view is correct, he would agree with the view that traffic laws do not limit our freedom, but would certainly disagree with the view that it has something to do with the rationality of our preferences. Laws which limit movement on roads do not violate freedom, while laws which limit the right to emigrate do so, not because some rational order of preferences exists, but because these are perceptions of citizens themselves. It is plausible to say that a citizen of the modern state will not see his freedom limited as a result of the traffic laws. Therefore, we do often think that there can be laws which leave us completely free. But we think so precisely because we grasp these laws as formal and not substantive, as establishing rules and not demanding actions. Now, one can also say that we do not think that traffic laws are substantive because we do not see them as implying some common goal. On the other hand, we do not ascribe to these laws any goal because we do not feel that they demand substantive performances.

In order to make this point clearer, let us deal with the objection that this view probably invites. It can be argued that, although 'freedom' may be not restricted by laws, actions are restricted, and therefore civil freedom may not mean the absence of constraint on actions. The answer to this is that, according to my interpretation, $n o$ action is perceived as restricted. A member of a society who recognizes the authority of lex sees himself as acting within its context and therefore does not regard any action beyond this legal context as a possible option. An analogy with language can clarify this claim. A user of a language in which a certain tense (like 'future continuous') does not exist is, in some sense, restricted from being able to say something which can be expressed only by using that tense. And yet it would be quite sensible to say that, within the context of that 
language, freedom of expression is unrestricted. Similarly, a car driver can choose different destinations and different routes, and his actions are unrestricted by the requirement that he should drive only on the left side, because he sees this requirement as a given context within which he tries to achieve his goals. Trespassing these requirements is never an option in so far as the conditions of civility are recognized. Analogously, human actions can never be seen as restricted by the physical impossibility of achieving some goal (like flying to the sun), because it is a given condition of human beings. Now, according to this interpretation, civil laws can be recognized in this manner only if they are not seen as enacted in order to promote some goal. Laws should not be seen as constraining us in achieving our life goals or as designed to hinder our choices.

Here lies the link between Oakeshott's advocacy of freedom and his emphasis on tradition. For only acquaintance with the cultural tradition and values of a certain society can show which choices and which life goals are regarded as important by the members of this society, and, therefore, which rules will be seen as limiting their freedom. Let us imagine a society in which for one reason or another the limitation on our movement in the streets is no longer seen as a set of formal rules that qualify citizens' performances, but as a mechanism invented to promote a certain social ideal. It is quite possible that many people would suddenly see in these laws unjustifiable limitation on their free choices. To take a more realistic example, one could analyse the change in the content and implementation of decency laws. Within a stricter, more Victorian morality these limitations could be reasonably grasped as merely qualifying rules, within which citizens could make their free choices. As cultural values changed and society became more tolerant, these laws had to undergo a change, since previous limitations might be seen as imposing substantive requirements. In other words, to deprive law of its character as lex is to show that this law does not establish the context in which people pursue their goals, but rather promotes some social goal and therefore restricts civil freedom.

Thus, in order to discern the character of a law, one should turn to the particular cultural milieu within which this law is enacted and interpreted. It is clear then why Oakeshott preferred the system of common law to the European codified law. Precedent law is more flexible and open to social changes. This claim by itself is not new. But Oakeshott provides it with a strong theoretical justification, emphasizing the link between the idea of freedom and certain features of the legal system.

Thus, for Oakeshott, citizens in a civil association are free because they are not constrained. They are not constrained because they do not think that laws limit their choices. This is because in the context of their tradition they have some perceptions of their possible purposes. Laws are not regarded as limiting these purposes and therefore prescribing substantial actions, but rather seen as creating the context in which individuals deliberate about their choices. This idea is central to the argument of On Human Conduct, but it can also be found in earlier 
writings of Oakeshott. Thus, he argues that to think of rights and duties as 'limitation' is 'a relic of an old intellectual error', for:

... it is an unfortunate way of thinking which is inherent in the simpler forms of a natural law conception of society. The truth is, however, that we do not begin by being free; the structure of our freedom is the rights and duties which, by long and painful human effort, have been established in our society. Individuality is not natural; it is a great human achievement. The conditions of individuality are not limitations; there is nothing to limit. And the adjustment of those conditions are not interference (unless they are overhead adjustments); they are the continuation of the achievement. ${ }^{40}$

Now, if this interpretation of civil freedom is at least coherent, even if not convincing, one can see how it fits into the general framework of Oakeshott's thought. For this concept is nothing else than the idea of 'recognized contingency' in the context of social relationships. The two elements - reflectivity and contingency - correspond to what Liddington defined as 'political' freedom and 'substantive' freedom. On the one hand, civil freedom presupposes the presence of choice to do this rather than that. On the other hand, it requires the awareness of an intelligent being of him having such a choice, and this awareness exists only when the laws are grasped as non-purposive. Contingency then must be recognized contingency.

This interpretation of civil freedom, however, leaves the way open to objections on the ground of its supposed relativism. For if freedom is determined by the non-purposive non-substantive character of law, if such character cannot be ascribed to any law objectively but only with regard to subjects' perceptions, and if, finally, these perceptions are conditioned by a specific cultural tradition, then how can one distinguish between free and unfree associations? Would it not mean that people in England and people in China just have different understandings of what their aspirations are and therefore of what will in effect limit these aspirations? Will the Chinese freedom be no less genuine, though a very different freedom?

Two answers can be given to this objection. First, the very complaint that this theory does not give a criterion according to which one can judge whether a certain society is free simply confirms Oakeshott's much-repeated claim that no political theory can serve as a guide for practical actions and evaluations. This is not just a failure of his specific approach; a similar charge of 'relativism' can be directed towards any theory which attempts to formulate its principles with at least some element of generality. In this sense the utilitarian approach is no more satisfactory. The utilitarian approach seems to provide us with a very good proof that Britain is a more free country than socialist Albania, but as Taylor showed, it can be also employed in order to present the opposite claim. ${ }^{41}$

Second, although there is no demonstrative a priori way to determine which society is free, the presuppositions of Oakeshott's theory can still be used, though not applied, on the practical level. ${ }^{42}$ For it will be possible to say to what extent a particular state is free if the perceptions of its members about the nature of its 
laws are known. Thus, if the citizens of the former Communist countries had thought about their laws as having an 'adverbial' character, if they had seen in the laws forbidding 'bourgeois' education a merely conditional requirement, one would have had to accept that they were no less free than the citizens of western liberal countries. But in fact they never believed in all these things. Although many of them supported their regimes, they did so not because they thought they had freedom. Thus, they were unfree not because their countries' laws were 'objectively' purposive, but because they themselves regarded these laws as purposive. This sort of answer was suggested by Oakeshott when he discussed the policies of socialists in his earlier article. Criticizing the claims that socialist policies meant the achievement of a more real freedom, he claimed:

A man who, before the Truck Act, was defrauded of his wages, knew himself to be, to that extent, a slave. He might be well-fed, secure in his job and enjoying a rising standard of living; nevertheless, he was not to be gulled into thinking that he was as free as he would be if his wages were paid him in cash. The Truck Act set him free. It did not say to him, 'The price of this freedom is a bit off the other end of your freedom': it was a gratuitous addition to his freedom made by a civilized society, and if it had not been this it would have not been freedom at all. And this All is the truth that has been lost in confusion: if you are required to pay with freedom for an offered freedom, you can be certain that what you are offered is not freedom at all, but something else. ${ }^{43}$

Here Oakeshott is quite certain that a modern individual has clear perceptions about freedom which prevent him from buying egalitarian ideologies packed as 'freedom'.

Likewise, Oakeshott is at pains to demonstrate that modern liberal democratic countries are free to a large extent, by showing that they are seen by many citizens as societas, and not universitas. This is especially true of political philosophers. According to Oakeshott, almost every modern political thinker, including Hobbes, Hegel and Fichte, intimated, if not explicitly expressed, the view of the modern society as a civil association. ${ }^{44}$ If my interpretation of his theory is correct, then it becomes clear why this is so important for him. To show that the best minds of the modern western states understood these states as civil associations means to show that these states are free states.

\section{Concluding Remarks}

Oakeshott understands freedom as a practical abstraction which comes to denote what I have described as a 'recognized contingency'. By this term I mean the awareness of one's own situation as contingent. In such a situation a person is aware of being himself an agent who can respond to a particular situation in different ways. His specific choice is not determined by his situation.

This concept of freedom can, however, be applied in different contexts, thus acquiring different meanings. In one context, freedom can be used as a concept distinguishing a 'human' from a 'non-human' being. Then it is to be understood 
as inherent in any human being. This is what I call 'human freedom'. In another context, freedom can refer to social relationships. In this context freedom is understood as being enjoyed by members of a society who perceive themselves as not being obliged to perform substantive actions. This is what I call 'civil freedom'.

'Human freedom' and 'civil freedom' are both called 'freedom' because they employ the same idea of 'recognized contingency'. Yet, when applied in those two contexts, the notion of 'recognized contingency' plays out differently. In the context of the discussion of what is 'human' it comes to mean the absence of determinacy, while in the context of social relationships it evokes the idea of the absence of constraint.

There is therefore no direct connection between 'human' and 'civil' freedom. Their relation is not that of identity. It is clear that 'human freedom' is applied universally to all human beings, and no one can be deprived of it, while many people can be deprived of 'civil freedom'. Nor can these two meanings be deduced from each other, refuted by each other, or shown to be contradictory. The relationship between them is not of logical (in)consistency, but that of logical irrelevance. The statement that someone is a free agent cannot teach us anything about his civil condition.

Confusion may arise, because in some places Oakeshott draws a parallel between 'human' and 'civil' freedom, pointing out that those who value civil freedom want to cherish their free agency. ${ }^{45}$ But here the connection is not logical but rather psychological. Thus, one who acknowledges oneself as a human being possessing freedom understood as recognized contingency is likely to attempt to apply this idea to his civil condition and thus demand 'civil freedom' in addition to 'human freedom' already enjoyed by him. Yet this awareness does not create any logical relation between the two meanings of freedom except that of analogy. For even those who are unhappy about their being in the condition of 'human freedom' are, nevertheless, free agents as well.

What conclusions can be drawn from our adoption of such a view of freedom? One is that Oakeshott's theory of freedom is closer to our common-sense perception of freedom than one could suggest at first glance. Thus, although his view on 'human freedom' has Stoic, Kantian and Hegelian overtones, there are two important qualifications. First, by combining it with the freedom of choice, Oakeshott moves closer to a typically empiricist view of freedom. Second, by insisting that 'freedom' in this sense is a postulate of human conduct, he rules out any application of it to our practical choices. No choice makes us less or more free.

Nor is the description of civil freedom significantly different from the liberal 'negative' idea of freedom. That freedom is implied in the generality of law may sound too closely resembling Rousseau's ideas. ${ }^{46}$ Nevertheless, the two authors are completely different. While for Rousseau, general law presupposes freedom, because it is a 'self-enacted' law, for Oakeshott, it presupposes freedom simply 
because lex literally does not constrain. Rousseau asks who is the author of law, when Oakeshott is concerned with what law actually does. Thus, the meaning of civil freedom turns out to be the absence of constraint, that is, the familiar idea of 'negative' liberty, though presented in quite a different way.

Another conclusion is that Oakeshott's position may shed light on the confused distinction between what are called 'negative' and 'positive' liberty. According to Isaiah Berlin, 'negative' freedom refers to the absence of constraint, whereas 'positive' freedom emphasizes self-determination and autonomy. ${ }^{47}$ One can find some parallels between Oakeshott and Berlin. Absence of constraint is implied in Oakeshott's understanding of civil freedom; and 'human freedom' may sound somewhat similar to the idea of human autonomy. But, according to Oakeshott, the meaning of freedom as 'human freedom' is irrelevant to any political considerations. It is the postulate of human conduct and therefore cannot be subject to any political or social project. Confusion crops up when the idea of human being as a 'free' agent acquires the status of a different kind of freedom which can be used by political philosophy, so that 'negative' liberty and 'positive' liberty are presented as two political alternatives. But as a political theorist Oakeshott belongs unambiguously to the camp of what is identified as 'negative' liberty simply because for him 'positive' political liberty does not exist.

The view advocated by Oakeshott also provides us with an elegant answer to the dilemma in which every theorist of 'negative' freedom is likely to find himself. For one is constrained to do something that he desires or may desire to do. One can argue, therefore, that freedom can be augmented not only by reducing limitations, but also by changing one's desires. Any attempt to present a radical solution to this problem leads to two opposite extremes.

There is a 'materialistic' view, advocated by Hillel Steiner, who defines freedom as 'the personal possession of physical objects' so that any increase in the number of physical objects controlled by one agent constitutes an increase of his freedom and a decrease of freedom of other agents to whom the control of these objects is consequently denied. ${ }^{48}$ This approach, however, is opposed to our basic intuitions. We are aware that there are meaningful preferences according to which freedom in some aspects is more valuable than freedom in others. This is the position of Charles Taylor. But from this assumption Taylor makes a logically unnecessary move towards the view that it is possible to evaluate different preferences. And thereby he rejects the liberal idea of 'negative' freedom. ${ }^{49}$

Oakeshott's view offers the way out of this dilemma. On the one hand, the element of 'reflectivity' in his view shows that a purely materialistic utilitarian view of freedom is absurd, and that freedom is lacking only when people recognize themselves as unfree. On the other hand, the element of contingency does not let this view collapse into the advocacy of freedom as 'recognized necessity' or like attempts to misuse freedom and eliminate the aspect of genuine choice and indeterminacy from human conduct.

Thus, by presenting this view, Oakeshott employs a vocabulary and arguments 
different from familiar common-sense utilitarian arguments. Yet his view is, in effect, a defence of the modern western liberal view of freedom, though from a different standpoint.

This liberalism should not be confused with political radicalism of the sort, advocated by Richard Flathman who argues that:

... if known politically organized associations ... are predominantly teleocracies, then human beings who treasure individuality, plurality, and freedom will (perhaps informed and emboldened by awareness of the contrasting ideal offered by Oakeshott) stand in a vigilant, defensive, even antagonistic posture towards their laws and other institutions and institutionalisms. ${ }^{50}$

This is not, however, Oakeshott's intention. His idea of freedom is indeed a liberal idea. But, according to Oakeshott, freedom has been actually achieved in modern liberal countries to a great extent. Thus, the idea of civil association should not be understood as an ideal of the perfectly free regime, but as the principle implied in many, though not all, institutions of modern liberal societies.

For Oakeshott, freedom is not an ideal, but an actual characteristic of western liberal society, in so far as it is understood as a civil association. As he wrote:

... the freedom which we enjoy is nothing more than arrangements, procedures of a certain kind: the freedom of an Englishman is not something exemplified in the procedure of habeas corpus, it $i$, at that point, the availability of that procedure. And the freedom which we wish to enjoy is not an 'ideal' which we premeditate independently of our political experience, it is what is already intimated in that experience. ${ }^{51}$

From what we have seen, this phrase should not be regarded as a conservative Burkean version of 'positive' freedom. This simply means that to know civil tradition is to know how people understand themselves, and what their values, habits and desires are. Only by learning this can we know whether their laws are understood as substantive or purposeless, and therefore know whether civil freedom exists or not in a given society.

\section{Notes}

I would like to thank Dan Avnon, David Runciman and Quentin Skinner for their helpful criticisms. Obviously all errors remain my own.

I. Noel O'Sullivan ( I 993) 'In the Perspective of Western Thought', in Jesse Norman (ed.) The Achievement of Michael Oakeshott, p. го . London: Duckworth.

2. John Liddington (1984) 'Oakeshott: Freedom in a Modern European State', in J. Gray and Z. Pelczynski (eds) Conceptions of Liberty in Political Philosophy, pp. 289-320. London: Athlone Press.

3. On Oakeshott's theory of freedom see also Anthony Farr (1998) Sartre's Radicalism and Oakeshott's Conservatism: The Duplicity of Freedom. London: Macmillan. Richard B. Friedman (1992) 'What is a Non-Instrumental Law?', Political Science Reviewer 2 I: 8 I-98. Steven A. Gerencser (I999) 'A Democratic Oakeshott?', Political Research Quarterly 52: 845-65. John Gray (1989) Liberalisms: Essays in Political Philosophy, pp. I99-2 I6. London: Routledge. David R. Mapel (I990) 'Civil Association and the Idea of Contingency', 
Political Theory i 8: 392-410. Mapel (1992) 'Purpose and Politics: Can there be a NonInstrumental Civil Association?', Political Science Reviewer 2 I: 63-80.

4. Michael Oakeshott (1975) On Human Conduct, p. 9. Oxford: Clarendon Press.

5. Ibid. p. 36 .

6. Josiah L. Auspitz (1976) 'Individuality, Civility, and Theory: The Philosophical Imagination of Michael Oakeshott', Political Theory 4: 27I.

7. Oakeshott (n. 4), p. 37 .

8. Michael Oakeshott (1989) 'A Place of Learning', in Timothy Fuller (ed.) The Voice of Liberal Learning, pp. 20-I. New Haven, CT: Yale University Press. This article was first presented at Colorado College as the Abbott Memorial Lecture in the Social Sciences in September 1974, i.e. at the time Oakeshott had just finished On Human Conduct.

9. Oakeshott (n. 4), p. $3^{8 .}$

ı. G.W.F. Hegel (1991) Elements of the Philosophy of Right, tr. H.B. Nisbet, B4. Cambridge: Cambridge University Press.

I I. Robert Devigne (1994) Recasting Conservatism: Oakeshott, Strauss, and the Response to Postmodernism, pp. I I 9-1 2 I. New Haven, CT: Yale University Press.

I2. Oakeshott (n. 8), p. I9.

I3. Oakeshott (n. 4), pp. 36-7.

I4. Ibid. p. I04.

15. See Michael Oakeshott (1999) On History and Other Essays, pp. 76-8. Indianapolis: Liberty Fund.

I6. Liddington (n. 2), pp. 299-300, distinguishes between freedom as the absence of causation and freedom as the absence of constraint. He interprets Oakeshott's view as seeing causation and constraint as mutually exclusive. In this sense freedom of human agency is understood as the absence of causation while civil freedom, discussed later, is the absence of constraint. This is what makes these two senses of freedom distinct or even contradictory. This distinction, in my view, is unnecessary and more likely to confuse rather than explain. Moreover, it has no foundations in the text. As I show, Oakeshott's concept of freedom is defined not by absence, but by presence. Freedom is the presence of recognized contingency, in the sense of both 'human' and 'civil' freedom.

I 7. Oakeshott (n. 4), p. 4I.

I 8. This is the subject of the second essay of On Human Conduct, called 'On the Civil Condition'.

I9. Ibid. pp. I I4-I8.

2o. Ibid. pp. I 2 I -3 O.

2 I. Ibid. pp. $157-8$.

22. Ibid. p. $58 \mathrm{n}$.

23. Wendell John Coats, Jr. (1985) 'Michael Oakeshott as Liberal Theorist', Canadian Journal of Political Science i 8: 780.

24. Liddington (n. 2), p. 306.

25. See Farr (n. 3), p. 200.

26. Liddington (n. 2), p. 3 I 3 .

27. As e.g. in the following passage: 'Yet while a great deal of silly and harmful legislation would still be possible under the Rule of Law, it is at least not likely that oppressive legislation would be passed under it. The requirement that the laws must be equally applicable to all, that nobody must have the power of dispensing from them, makes this highly improbable. I will admit that some religious fanatics might wish to enforce general rules which others would feel as very severe restrictions of their liberty. But there are at least few rational grounds on which men could wish to impose upon all such restrictions - and where it might be attempted, as in the case of the prohibition of alcoholic drinks 
and the like, such restrictions are not likely to remain long effective if a substantial number of people regard them as oppressive'. F.A. Hayek (1955) The Political Ideal of the Rule of Law, p. 47. Cairo: National Bank of Egypt.

28. Coats (n. 23), p. 777.

29. See e.g. Mapel (1990, in n. 3).

30. Oakeshott (n. 4), p. I 78.

3I. Ibid. p. 158 .

32. See n. 25.

33. Gerencser (n. 3).

34. Michael Oakeshott (1991) 'The Political Economy of Freedom', in Rationalism in Politics and Other Essays, p. 391. Indianapolis: Liberty Fund.

35. Oakeshott (n. 4), pp. I $57-8$; italics are mine.

36. Liddington (n. 2), p. 297 , n. 65 .

37. Oakeshott (n. 4), p. I 84 .

38. Jeremy Rayner (1985) 'The Legend of Oakeshott's Conservatism: Sceptical Philosophy and Limited Politics', Canadian Fournal of Political Science I 8: 33 I.

39. Charles Taylor (I99I) 'What's Wrong with Negative Liberty', in D. Miller (ed.) Liberty, pp. I4I-62. Oxford: Oxford University Press.

40. Michael Oakeshott (I948) 'Contemporary British Politics', Cambridge Fournal I: 488.

4I. Taylor (n. 39), pp. I 50-I.

42. "The maxim of the Cardinal de Retz that "what is absolutely necessary can never be dangerous" is not unusable; but since "necessity" in conduct is always a matter of surmise, it can only be used, not applied.' Oakeshott (n. 4), p. 9 In.

43. Oakeshott (n. 40), p. 484.

44. Oakeshott (n. 4), p. $25^{2}$.

45. Ibid. pp. $235^{-6}$.

46. See J.-J. Rousseau (1997) The Social Contract and Other Later Political Writings, tr. V. Gourevitch, pp. 66-8. Cambridge: Cambridge University Press.

47. Isaiah Berlin (1969) 'Two Concepts of Liberty', in Four Essays on Liberty, pp. I I 8-72. Oxford: Oxford University Press.

48. Hillel Steiner (1991) 'Individual Liberty', in Liberty, pp. I $3{ }^{8-9 .}$

49. Taylor (n. 39).

50. Richard E. Flathman (1998) Reflections of a Would-Be Anarchist: Ideals and Institutions of Liberalism, p. 76. Minneapolis: University of Minnesota Press.

5 I. Michael Oakeshott (I99I) 'Political Education', in Rationalism in Politics and Other Essays, p. 54. Indianapolis: Liberty Fund. 